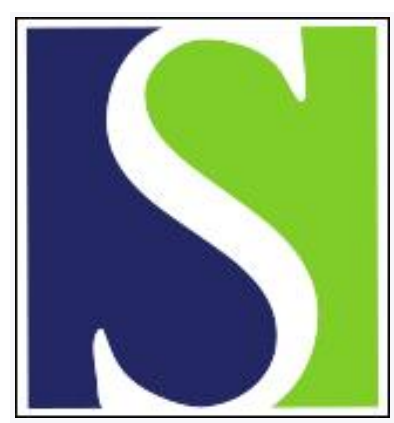

Scand J Work Environ Health 1994;20(1):48-54

https://doi.org/10.5271/sjweh.1429

Issue date: 01 Feb 1994

Respiratory symptoms and bronchial reactivity among pig and dairy farmers.

by Choudat D, Goehen M, Korobaeff M, Boulet A, Dewitte JD, Martin $\mathrm{MH}$

Affiliation: Departement de medecine du travail, Faculte de medecine Cochin, Port-Royal, Paris, France.

This article in PubMed: www.ncbi.nlm.nih.gov/pubmed/8016599

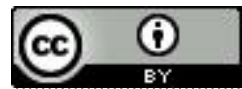




\title{
Respiratory symptoms and bronchial reactivity among pig and dairy farmers
}

\author{
by Dominique Choudat, MD, ${ }^{1}$ Michel Goehen, $\mathrm{MD},{ }^{2}$ Myriam Korobaeff, $\mathrm{PhD},{ }^{3}$ Alain Boulet, $\mathrm{PhD},{ }^{4}$ \\ Jean Dominique Dewitte, MD, ${ }^{5}$ Marie Hélène Martin, $\mathrm{MD}^{2}$
}

\begin{abstract}
CHOUdAT D, GOEHEN M, KOROBAEFF M, BOULET A, DEWITTE JD, MARTIN MH. Respiratory symptoms and bronchial reactivity among pig and dairy farmers. Scand $J$ Work Environ Health 1994;20:48 - 54. ObJectives - This study assessed the prevalence of respiratory manifestations among French pig and dairy farmers and determined the relationship between bronchial reactivity and respiratory manifestations. Methods - The pig farmers included 102 men working more than halftime inside swine confinement buildings. There were 51 male dairy farmers and 81 male referents. The demographic characteristics of the three groups were similar except for more smokers among the referents. Each subject completed a standardized questionnaire. Pulmonary function tests were performed before and after a methacholine challenge (cumulative doses 80, 240, and $560 \mu \mathrm{g}$ ). Airborne dust, ammonia, and carbon dioxide were measured inside 28 swine confinement buildings. RESULTs - The pig farmers were exposed to a total dust level of $2.41 \mathrm{mg} \cdot \mathrm{m}^{-3}$. The respirable particle concentration was low. The pig and dairy farmers had a significantly higher prevalence of cough and morning phlegm than the referents. Before the methacholine challenge, the dairy farmers had nonsignificantly lower mean lung function values than the other groups. Among the subjects with no history of asthma, nonspecific bronchial hyperreactivity was significantly higher among the pig and dairy farmers than among the referents. There was a fall in the forced expiratory volume in $1 \mathrm{~s}\left(\mathrm{FEV},{ }_{1}\right)$ that was greater than $10 \%$ in $6.7 \%$ of the referents, $17.9 \%$ of the swine workers, and $35.6 \%$ of the dairy farmers. This result was unchanged after adjustment for the initial FEV . Conclusions - The prevalence of respiratory symptoms was significantly higher among the pig farmers without base-line lung function impairment. However, both the pig and the dairy farmers had increased bronchial reactivity.
\end{abstract}

Key terms: agricultural workers, epidemiology, occupational airborne exposure.

Epidemiologic studies have demonstrated an increased risk of respiratory dysfunction among farmers (1-4) and, especially, among workers in swine confinement buildings (5-24). These studies identified the following characteristics of pig farmers in different countries: (i) a higher prevalence of respiratory symptoms, including chronic bronchitis and asthma than in a reference group, (ii) nonrespiratory symptoms consistent with the organic dust toxic syndrome; (iii) similar or only slightly lower lung function values as compared with reference groups, (iv) no change or only small decreases in lung func-

1 Département de médecine du travail, Faculté de médecine Cochin - Port-Royal (Department of Occupational Medicine, Faculty of Medicine Cochin-Port-Royal), Paris, France.

2 Mutualité sociale agricole (Rural National Health Service), France.

3 Institut national de la santé et de la recherche médicale (National Institute of Health and Medical Research), INSERM U 226, Paris, France.

4 Institut national de recherche et de sécurité (National Institute of Research and Security), INRS, Vandoeuvre, France.

5 Centre hospitalo-universitaire Morvan (University Hospital Morvan), Brest, France.

Reprint requests to: Dr D Choudat, Faculté de médecine Cochin-Port-Royal, Département de médecine du travail, 24 rue du faubourg Saint-Jacques, 75014 Paris, France. tion values during the workshift. The following airborne agents in swine confinement buildings have been suggested as being responsible for these respiratory manifestations: organic dust, microorganisms, endotoxins, and gases including ammonia and hydrogen sulfide $(8,10,15,20,21,23,25-30)$. The pathogenesis of these symptoms has not yet been established $(24,31)$.

However, previous studies have reported an increase in nonspecific airway responsiveness among pig farmers. Acute exposure in swine confinement buildings caused bronchial hyperresponsiveness among six healthy subjects (30). Swine confinement workers have slightly higher nonspecific airway responsiveness than outdoor blue-collar workers (22) and referent workers (32). Moreover, nonspecific bronchial reactivity correlates with duration of exposure among pig farmers (17). However, the hyperreactivity found among pig farmers is not significantly different from that found among dairy farmers (17, 32). These studies comparing pig farmers with either dairy farmers or other referents suggest an increased nonspecific airway responsiveness among pig farmers and probably also among dairy farmers. Only one study did not find bronchial hyperresponsiveness in pig farmers (33).

The western region of France has a particularly high density of pig farms. There are about 150000 people working on pig farms, including 30000 who 
work in swine confinement buildings. No data is currently available about the respiratory health of French pig farmers. Therefore, we initiated a cross-sectional epidemiologic study to assess the prevalence of respiratory manifestations among French pig and dairy farmers and to determine the possible role of bronchial reactivity in the respiratory manifestations by comparing farmers with people not exposed to pigs or the farm environment.

\section{Subjects and methods}

\section{Population}

All of the subjects were selected from the Rural National Health Service register for two districts of western France. The group of pig farmers was chosen first. All swine confinement producers with more than 50 sows or more than 800 pigs were selected. In farms of this size at least one worker spends more than half of his or her worktime inside the swine confinement buildings. Each pig farmer was visited at his or her residence and asked to participate in the study. One hundred and sixty-four pig farmers were visited, and $138(84.1 \%$ ) were included in the study. Women were excluded because they had different patterns of possible confounding factors. They were older than the men ( 43.2 versus 39.7 years, $P=0.08$ ), the prevalence of smokers was lower (5.6 versus $\left.28.4 \%, \mathrm{P}<10^{-4}\right)$, and the type of work and duration of exposure inside the swine confinement buildings were different. The study group was thus 102 men (group P).

Two reference groups were then selected from the same register according to a similar recruiting program. The men were not confinement swine producers. They were matched for age ( \pm 5 years) and county of residence.

One hundred and twenty-one farmers other than pig producers were chosen, of which 101 persons $(83.5 \%)$ responded. All 36 women and 14 subjects who were ex-swine producers or poultry breeders were excluded. The group of dairy farmers thus contained 51 men (group D).
A second reference group was drawn from the list of workers in the dairy industry who were not exposed to any air contaminants. A sample of 125 subjects was selected, and 115 persons $(92.0 \%)$ were studied. Twenty-five women and nine men were exswine producers, poultry breeders, or dairy farmers and were therefore excluded. The group of reference workers was thus 81 men (group R).

The study was conducted over three weeks in May 1989.

The demographic characteristics of the three groups are presented in table 1 . The smoking habits of groups $\mathrm{P}$ and $\mathrm{D}$ were similar. The percentage of smokers in group $\mathrm{R}$ was higher than in groups $\mathrm{P}$ $\left(\mathrm{P}<10^{-4}\right)$ and $\mathrm{D}\left(\mathrm{P}<10^{-4}\right)$.

\section{Questionnaire}

Each subject completed a questionnaire about personal characteristics, respiratory symptoms, smoking habits, and occupational history. Nonsmokers were defined as those with a lifelong abstinence from smoking and ex-smokers as those who had ceased smoking completely at least six months before the study. The questions on respiratory symptoms were translated from the questionnaires of the British Medical Research Council and of the International Union Against Tuberculosis and Lung Disease. They addressed, among other things, the following items: usual and morning cough, phlegm, wheezing during the last 12 months, shortness of breath, and a description of breathing. Additional questions on work-related symptoms such as rhinitis, irritation of the eyes, and respiratory symptoms were included.

\section{Pulmonary function tests}

Pulmonary function tests were performed on each subject with the use of a computerized pneumotachograph Fleish no 3 (Spiromatic, ets MSR). The spirometer was calibrated each day with a $1.5-1$ syringe. At least three satisfactory forced maximal expirations were performed by each subject while he was seated and wearing a noseclip.

The highest forced vital capacity (FVC), highest forced expiratory volume during $1 \mathrm{~s}\left(\mathrm{FEV}_{1.0}\right)$, and

Table 1. Demographic characteristics of the pig farmers (group P), dairy farmers (group D), and the reference group (group R).

\begin{tabular}{|c|c|c|c|c|c|c|c|c|c|c|c|c|}
\hline \multirow[t]{2}{*}{ Group } & \multirow[t]{2}{*}{ Number } & \multicolumn{2}{|c|}{$\begin{array}{c}\text { Age } \\
\text { (years) }\end{array}$} & \multicolumn{2}{|c|}{$\begin{array}{l}\text { Height } \\
\text { (cm) }\end{array}$} & \multicolumn{2}{|c|}{$\begin{array}{l}\text { Weight } \\
\text { (kg) }\end{array}$} & \multicolumn{2}{|c|}{$\begin{array}{l}\text { Length of } \\
\text { employment } \\
\text { (years) }\end{array}$} & \multicolumn{3}{|c|}{ Smoking status } \\
\hline & & Mean & $S D$ & Mean & SD & Mean & $\mathrm{SD}$ & Mean & SD & $\begin{array}{c}\text { Non- } \\
\text { smokers } \\
(\%)\end{array}$ & $\begin{array}{c}\text { Smokers } \\
(\%)\end{array}$ & $\begin{array}{c}\text { Ex- } \\
\text { smokers } \\
(\%)\end{array}$ \\
\hline $\begin{array}{l}P \\
D \\
R\end{array}$ & $\begin{array}{r}102 \\
51 \\
81\end{array}$ & $\begin{array}{l}39.7 \\
40.1 \\
38.5\end{array}$ & $\begin{array}{l}11.7 \\
11.7 \\
10.3\end{array}$ & $\begin{array}{l}175 \\
172 \\
173\end{array}$ & $\begin{array}{l}7^{*+} \\
6 \\
6\end{array}$ & $\begin{array}{l}73.2 \\
71.1 \\
75.2\end{array}$ & $\begin{array}{l}8.6 \\
9.4^{\star *} \\
10.1\end{array}$ & $\begin{array}{l}15.7 \\
20.3 \\
15.7\end{array}$ & $\begin{array}{l}10.0^{++} \\
14.0^{\star} \\
8.8\end{array}$ & $\begin{array}{l}54.9 \\
58.8 \\
24.7\end{array}$ & $\begin{array}{l}28.4^{* * *} \\
27.4^{* \star *} \\
44.4\end{array}$ & $\begin{array}{l}16.7 \\
13.7 \\
30.9\end{array}$ \\
\hline
\end{tabular}

* $\quad P<0.05$; significantly different from group $R$.

** $P<0.01$; significantly different from group $R$.

*** $P<0.001$; significantly different from group $R$.

$+\quad P<0.05$; significantly different from group $D$.

$++P<0.01$; significantly different from group $D$. 
highest peak flow rate (PF) were recorded, not necessarily from the same test. The other forced expiratory flow rates were taken from the curve with the highest sum of the FVC and $\mathrm{FEV}_{1.0}$ : forced expiratory flow between $25 \%$ and $50 \%$ of the FVC (MEF), and maximal expiratory flow rates at $75 \%, 50 \%$, and $25 \%$ of the FVC still to be expired $\left(\mathrm{FEF}_{75}, \mathrm{FEF}_{50}\right.$, and $\mathrm{FEF}_{25}$, respectively).

All of the values were expressed as percentages of predicted values from the European Committee for Coal and Steel and Bouhouys. To avoid bias from age, height, and smoking habits in the lung function measurements, standardized deviations were used for the statistical analyses (ie, the observed value minus the predicted value divided by the residual standard deviation).

\section{Methacholine challenge}

Bronchoconstrictor challenge was performed with an automatic device (FDC 88, Et Mediprom) that vaporizes a dose of methacholine at the beginning of inhalation. The solution of methacholine $(1 \mathrm{mg}$. $\mathrm{ml}^{-1}$ ) was vaporized by a De Vilbiss 646 nebulizer powered by an air compressor. The inhalations were done while the subject was seated and wearing a noseclip. Each dose contained $40 \mu \mathrm{g}$ of methacholine, and the spirometric variations were recorded 2 or $3 \mathrm{~min}$ after cumulative doses of 80,240 , and $560 \mu \mathrm{g}$ of methacholine. The challenge was not performed if the subject had an observed $\mathrm{FEV}_{1,0}$ : predicted $\mathrm{FEV}_{1.0}$ ratio of less than $70 \%$, and it was stopped after a decrease of $20 \%$ of the $\mathrm{FEV}_{1,0}$.

For the analysis of the methacholine challenge, we compared the prevalence of the subjects with a fall in $\mathrm{FEV}_{1.0}$ that was greater than 10,15 , and $20 \%$. They were considered responders. (See table 5 in the Results section.) The decrease in FEV ${ }_{1.0}$ was less than $10 \%$ for many of the subjects. The dose-response slopes were calculated for each subject as the ratio between the percentage of the variation from the initial value of the $\mathrm{FEV}_{1.0}$ and the final cumulative methacholine dose administered as follows (34):

$\left[\left(\mathrm{FEV}_{1.0}\right.\right.$ final $-\mathrm{FEV}_{1.0}$ initial $) /\left(\mathrm{FEV}_{1.0}\right.$ initial $\times$ final dose) $\times 100$.

Table 2. Airborne concentrations of various contaminants in swine confinement buildings.

\begin{tabular}{lrrr}
\hline Contaminant & $\begin{array}{c}\text { Number } \\
\text { of } \\
\text { samples }\end{array}$ & Mean & Range \\
\hline Airborne dust $\left(\mathrm{mg} \cdot \mathrm{m}^{-3}\right)$ & & & \\
$\quad$ Total dust & 21 & 2.41 & $0.29-8.55$ \\
$\quad$ Inspirable particles & 28 & 1.82 & $0.23-6.71$ \\
$\quad \begin{array}{l}\text { Respirable fraction } \\
\text { Dust individual exposure }\left(\mathrm{mg} \cdot \mathrm{m}^{-3}\right)\end{array}$ & 24 & 0.17 & $0.01-0.52$ \\
$\quad$ Inspirable particles & 4 & 3.63 & $1.63-7.51$ \\
Airborne ammonia $\left(\mathrm{mg} \cdot \mathrm{m}^{-3}\right)$ & 48 & 8.50 & $0.80-28.3$ \\
$\begin{array}{l}\text { Ammonia, individual exposure } \\
\left(\mathrm{mg} \cdot \mathrm{m}^{-3}\right)\end{array}$ & 4 & 3.23 & $0.60-5.90$ \\
\hline
\end{tabular}

\section{Environmental assessments}

Airborne dust, ammonia, and carbon dioxide were measured inside 28 swine confinement buildings on six pig farms (table 2). Samples were taken from sites considered to represent the typical work environment in the building.

Total dust, inspirable particles, and the respirable fraction were determined for each site (35). Inspirable particles in the breathing zone of the workers were also determined with personal sampling pumps. The dust was collected on 25-mm polyvinyl chloride filters with or without cyclone separators. Some of the dust samplers were equipped with Nuclepore filters for electronic microscopy. The particles were identified by scanning electron microscopy with Xray energy spectrometry.

Ammonia in the sites from which the dust samples were taken was measured using Dräger colorimetric tubes, and the carbon dioxide concentration was determined by spectrophotometry (Binos 1). Ammonia was also assayed by personal sampling. Filters were impregnated with sulfuric acid, and the ammonia was measured by ionic chromatography (Dionex).

The measurement of endotoxins is not possible in France. The environment was not assessed on the small dairy farms, which are scattered over the region. The dairy farmers had varied activities. They do not work in confinement buildings but often work in the open air.

\section{Statistical analysis}

Standard descriptive statistics were used to represent the responses. Chi-squared tests were used with $2 \times 2$ contingency tables to determine whether the relationships between the qualitative variables were statistically significant, and the Mantel-Haenszel analysis was used to determine the relative risk. Discrete variables were corrected for smoking. An analysis of variance was used to examine the relationships between pulmonary function and respiratory symptoms, work exposure, and smoking. The continuous variables were corrected for age, height, and smoking.

The treatment of the data was performed with an SAS (Statistical Analysis System) package.

\section{Results}

The workers on the pig farms were exposed, on the average, to a total dust level of $2.41 \mathrm{mg} \cdot \mathrm{m}^{-3}$. However, the amount of respirable particulate matter was low (table 2). Electron microscopy indicated large organic particles (figure 1). The amount of ammonia varied from 0.60 to $5.9 \mathrm{mg} \cdot \mathrm{m}^{-3}$ between buildings. The concentration of carbon dioxide was low (1000 to $5000 \mathrm{ppm}$ ). The peak concentrations of carbon dioxide occurred when the pigs were excited by the farmer entering the buildings (figure 2). 
The distribution of positive responses to the question "Have you ever had asthma?" was similar in the three groups, four subjects in group $\mathrm{P}$, three in group $\mathrm{D}$, and three in group R. Excluding asthmatics did not change the demographic characteristics of the groups.

The prevalence of respiratory symptoms did not differ between group $P$ and $D$ except for work-related fits of coughing $(\mathrm{P}<0.02)$ (table 3$)$. These two groups had a slightly higher prevalence of cough and morning phlegm than group $\mathrm{R}$ did. These differences were significant even after adjustment for smoking habits.

Respiratory symptoms were significantly more frequent during work in groups $\mathrm{P}$ and $\mathrm{D}$ than in group $\mathrm{R}$ (table 3). Very few farmers reported delayed, work-related symptoms.

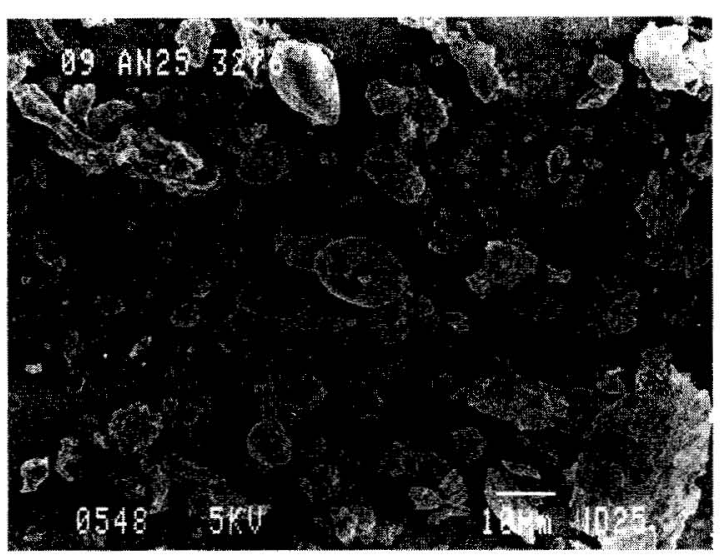

Figure 1. Scanning electron micrograph of airborne particles collected in a swine confinement building.
Before the methacholine challenge, the mean lung function values were normal according to the European reference values. The dairy farmers had lower values, but there was no significant difference between the groups (table 4). No significant correlation was observed between duration of employment and the lung function values, adjusted for age, height, and smoking habits.

Two subjects in group $\mathrm{P}$, two in group $\mathrm{D}$, and one in group $\mathrm{R}$ could not undergo bronchoconstrictor challenge because their initial pulmonary function values were too low. One subject in group $\mathrm{P}$, one in group $\mathrm{D}$, and two in group $\mathrm{R}$ stopped the challenge at cumulative doses below $560 \mu \mathrm{g}$.

The methacholine challenge induced a significant decrease in lung function in all three groups.

Bronchial hyperreactivity to methacholine challenge was significantly higher among the dairy and pig farmers than among the referents, with higher prevalences of responders and lower negative mean slopes (table 5 ). Only four subjects $(1.8 \%$ ) had a decrease in $\mathrm{FEV}_{1.0}$ that was greater than $20 \%$. The findings were unaffected by adjustment for the initial $\mathrm{FEV}_{1.0^{\circ}}$

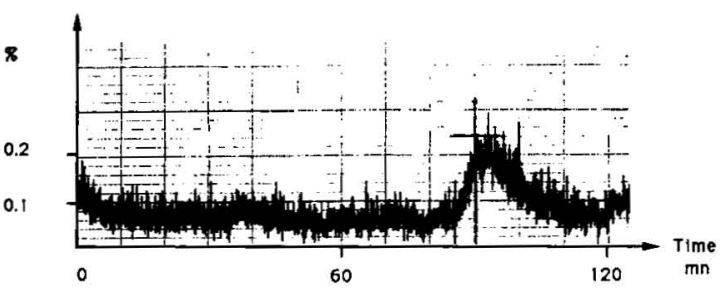

Figure 2. Carbon dioxide concentration in a swine confinement building. Peak induced by the farmer entering.

Table 3. Prevalence of respiratory symptoms. Comparisons between pig farmers (group P), dairy farmers (group D) and the reference group (group R).

\begin{tabular}{|c|c|c|c|c|c|c|c|c|c|c|c|c|c|c|}
\hline \multirow[b]{2}{*}{ Group } & \multirow[b]{2}{*}{$\begin{array}{l}\text { Morning } \\
\text { cough }\end{array}$} & \multirow[b]{2}{*}{$\begin{array}{l}\text { Diurnal } \\
\text { cough }\end{array}$} & \multirow[b]{2}{*}{$\begin{array}{l}\text { Fits of } \\
\text { coughing }\end{array}$} & \multirow[b]{2}{*}{$\begin{array}{l}\text { Morning } \\
\text { phlegm }\end{array}$} & \multirow[b]{2}{*}{$\begin{array}{c}\text { Chest } \\
\text { tightness }\end{array}$} & \multirow[b]{2}{*}{$\begin{array}{l}\text { Wheez- } \\
\text { ing }\end{array}$} & \multirow[b]{2}{*}{$\begin{array}{l}\text { Short- } \\
\text { ness of } \\
\text { breath }\end{array}$} & \multirow[b]{2}{*}{ Sneezing } & \multirow[b]{2}{*}{ Rhinitis } & \multicolumn{5}{|c|}{ Work-related } \\
\hline & & & & & & & & & & $\begin{array}{c}\text { Fits of } \\
\text { coughing }\end{array}$ & $\begin{array}{c}\text { Sneez- } \\
\text { ing }\end{array}$ & Rhinitis & $\begin{array}{l}\text { Wheez- } \\
\text { ing }\end{array}$ & $\begin{array}{l}\text { Short- } \\
\text { ness of } \\
\text { breath }\end{array}$ \\
\hline$P(N=98)$ & $\begin{array}{c}13.3^{*} \\
P=0.03\end{array}$ & $\begin{array}{r}13.3^{* *} \\
P=0.004\end{array}$ & $P=0.009$ & 10.2 & 3.1 & 7.1 & 12.2 & 29.6 & 10.2 & $\begin{array}{c}24.5^{* * *} \\
P=0.0004\end{array}$ & $\begin{array}{c}21.4^{*} \\
P=0.03\end{array}$ & 15.3 & 2.0 & 3.1 \\
\hline $\mathrm{D}(\mathrm{N}=48)$ & 10.4 & 6.2 & $\begin{array}{r}22.9^{*} \\
P=0.03\end{array}$ & 16.7 & $\begin{array}{c}10.4^{*} \\
P=0.03\end{array}$ & 8.3 & 14.5 & 25.2 & 8.3 & 8.3 & 10.4 & 6.2 & 0 & 2.1 \\
\hline$R(N=78)$ & 3.8 & 1.3 & 9.0 & 7.7 & 1.3 & 5.1 & 16.7 & 19.2 & 15.4 & 5.1 & 9.0 & 15.4 & 1.3 & 5.1 \\
\hline
\end{tabular}

Table 4. Lung function values before methacholine challenge in the three groups. The values have been adjusted for age, height,

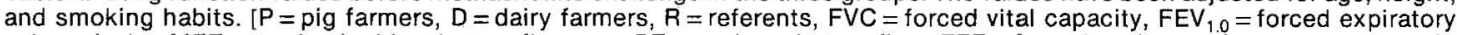
volume in $1 \mathrm{~s}, M E F=$ maximal midexpiratory flow rate, $P F=$ peak expiratory flow, FEF $=$ forced expiratory flow rate at a certain percentage (figure in subscript) of the forced vital capacity].

\begin{tabular}{|c|c|c|c|c|c|c|c|c|c|c|c|c|c|c|}
\hline \multirow{2}{*}{ Group } & \multicolumn{2}{|c|}{ FVC (I) } & \multicolumn{2}{|c|}{ FEV $_{1.0}(\mathrm{I})$} & \multicolumn{2}{|c|}{$\operatorname{MEF}\left(I \cdot s^{-1}\right)$} & \multicolumn{2}{|c|}{$P F\left(1 \cdot s^{-1}\right)$} & \multicolumn{2}{|c|}{$\operatorname{FEF}_{75}\left(I \cdot s^{-1}\right)$} & \multicolumn{2}{|c|}{$\mathrm{FEF}_{50}\left(1 \cdot s^{-1}\right)$} & \multicolumn{2}{|c|}{$\mathrm{FEF}_{25}\left(I \cdot \mathrm{s}^{-1}\right)$} \\
\hline & Mean & SD & Mean & SD & Mean & SD & Mean & SD & Mean & SD & Mean & $S D$ & Mean & SD \\
\hline$P\langle N=97\rangle$ & 5.04 & 0.85 & 4.05 & 0.72 & 4.20 & 1.29 & 9.06 & 1.61 & 7.76 & 1.79 & 5.00 & 1.55 & 1.92 & 0.74 \\
\hline$D(N=48)$ & 4.95 & 0.93 & 3.97 & 0.87 & 3.72 & 1.32 & 8.36 & 1.81 & 6.79 & 1.97 & 4.24 & 1.47 & 1.85 & 0.76 \\
\hline$R(N=78)$ & 5.04 & 0.73 & 4.07 & 0.63 & 4.20 & 1.15 & 8.34 & 1.60 & 7.29 & 1.63 & 5.01 & 1.41 & 1.94 & 0.74 \\
\hline
\end{tabular}


Table 5. Prevalence (\%) of subjects with a decrease in forced expiratory volume in $1 \mathrm{~s}$ equal to or greater than $10 \%$ (responders 10 ) and $15 \%$ (responders 15) and the mean of the slope of the bronchial reactivity by group. The reactivity was higher in groups $P$ and $D$ than in group $R$. (group $P=$ pig farmers, group $D=$ dairy farmers, group $R=$ referents)

\begin{tabular}{|c|c|c|c|}
\hline Variable & Group P & Group D & Group R \\
\hline $\begin{array}{l}\text { Responders } 10 \\
\text { (prevalence) }\end{array}$ & $\begin{array}{l}17.9 \\
\longleftarrow\end{array}$ & $\begin{array}{l}\frac{35.6}{L} P=0.03 \\
P=0\end{array}$ & $0001^{6.7}$ \\
\hline $\begin{array}{l}\text { Responders } 15 \\
\text { (prevalence) }\end{array}$ & 6.3 & 17.8 & $.02 \stackrel{4.0}{\longrightarrow}$ \\
\hline $\begin{array}{l}\text { Slope of reactivity } \\
\text { (mean, } \% \cdot \mu \mathrm{g})\end{array}$ & -12.4 & -17.5 & $.07 \stackrel{-9.7}{-}$ \\
\hline
\end{tabular}

\section{Discussion}

Several airborne contaminants are present in pig confinement buildings. In this study, the mean levels of ammonia, carbon dioxide, and dust were lower than the threshold limit values. However, there may be synergistic effects between toxic agents. The levels of these agents were similar or lower than the concentrations observed in Canada (10), Sweden $(8,15)$, the United States $(25,26)$, Finland (29), The Netherlands (27), and Yugoslavia (23). The dust was mainly composed of organic particles. The size of these particles, evaluated with the aid of both samplers and electronic microscopy, were about 5-10 $\mu \mathrm{m}$. This finding is consistent with those of Haglind \& Rylander (8), Crook et al (20), and Donham et al $(26,36)$. The inhalation of endotoxins may play a role in the occurrence of febrile reaction and respiratory manifestations among swine confinement workers $(8,18,20,21,27)$. The endotoxin level correlates with base-line FVC (21) and also with change in $\mathrm{FEV}_{1.0}$ over a work period (15). Endotoxins may thus increase bronchial reactivity. However, it is not known whether endotoxins alone are responsible for the change in bronchial responsiveness caused by inhaled swine dust $(28,30,32)$. For technical reasons, exposure to endotoxins was not assessed in our study.

We compared pig farmers, dairy farmers, and referents. Many previous studies have compared pig farmers to only one reference group, either dairy farmers or other referents. The use of nonpig farmers as referents is debatable, as they may be exposed to various airborne contaminants. They have a higher prevalence of respiratory symptoms and function abnormalities than nonfarm workers $(2-4,10,19)$. On the other hand, the prevalence of smokers was lower among the farmers than among the nonfarmers in our study population, and in Italy (2) and Canada $(19,22)$.

This cross-sectional study may have been biased by the "healthy worker effect." However, we identified a higher prevalence of respiratory symptoms among the pig farmers and among farmers not involved in intensive breeding than among nonfarm- ing references workers. There was no significant difference between the prevalence of respiratory symptoms in the two farming groups. However, respiratory symptoms were more prevalent in both groups of farmers than in the group of nonfarmers, despite lower percentages of smokers. The pig farmers especially reported symptoms of cough, fits of coughing, and phlegm. The prevalence of wheezing, chest tightness, shortness of breath, and asthma were not significantly different between the pig farmers and referents. Various respiratory symptoms have been identified among pig farmers in previous studies. For example, a higher prevalence of airway irritation and bronchitis was found in several studies $(8,9,12,14$, $15,17,19,22,23$ ), and sometimes a higher prevalence of asthma $(11,16)$ and symptoms of bronchial hyperreactivity (13) were revealed.

In the three groups, the mean base-line FVC and $\mathrm{FEV}_{1.0}$ were similar to the European reference values. The mean MEF, $\mathrm{FEF}_{50}$, and $\mathrm{FEF}_{25}$ were slightly lower than the reference values but without significant differences between the three studied groups even when smoking habits were taken into account. Lung function values were also slightly lower for the reference farmers than for the pig farmers in the study of Holness et al (10). Lower lung function values were also found by Dalphin et al (3) among French dairy farmers.

Bongers et al (9) found mean pulmonary function values, except for FVC, that were lower than the reference values among 132 pig farm owners. However, consistent with our study, there was no significant correlation between duration of exposure and pulmonary function. They did not study other farmers or reference groups. In contrast, Iversen et al (16) demonstrated that a low $\mathrm{FEV}_{1.0}$ correlated with the number of years in pig farming and also with bronchial hyperreactivity in a subgroup of symptomatic farmers without asthma. Therefore, bronchial hyperreactivity has been suggested to be involved in the higher prevalence of respiratory disease among farmers, especially among pig producers $(16,36)$.

Our doses of methacholine may have been too low to identify the hyperreactive subgroup unambiguously. The doses were however sufficient to reveal higher hyperreactivity in the farming groups than in the nonfarming group. This finding confirms the higher hyperreactivity observed by Zhou et al (22) among 20 pig farmers as compared with outdoor urban workers and by Rylander et al (32) among 36 pig farmers as compared with 16 referents, but not between the pig farmers and 23 dairy farmers. Iversen et al (16) studied bronchial reactivity by determining the provocative concentration of histamine causing a $20 \%$ decrease in peak expiratory flow. They found that most of the hyperreactivity among farmers was explained by a low FEV 1.0 . Moreover, they found that the hyperresponsiveness was slightly higher among pig farmers than among dairy farmers, but the difference was not significant (17). 
The lower initial $\mathrm{FEV}_{1.0}$ did not completely explain our results. The increase in the nonspecific hyperreactivity among the pig and dairy farmers was independent of the initial $\mathrm{FEV}_{1.0}$. Further studies are required to characterize the causative agents of respiratory symptoms and hyperreactivity among farmers.

\section{Acknowledgments}

We thank the farmers and the workers for their participation. We also thank $\mathrm{Mr} \mathrm{JC}$ Bellec, $\mathrm{Mr}$ Y Gelard, Mr G Maillard, Mr S Arab, Mr B Delemotte, Ms N Altmeyer, Ms C Frisch, Ms C Gimenez, Ms P Sauvaget and Ms $S$ Bruat for their help and advice and Ms B Najac for typing the manuscript.

This work was supported by grants from Caisses Centrales de Mutualité Sociale Agricole.

\section{References}

1. Dosman JA, Graham BL, Hall D, Van Loon P, Bhasin P, Froh F. Respiratory symptoms and pulmonary function in farmers. J Occup Med 1987;29:38-43.

2. Siracusa A, Pannelli F, Volpi R, Cresci A, Mollichella E, La Rosa F, et al. Studio trasversale sulla sintomatologia respiratoria e sulla funzione ventilatoria in un gruppo di 462 agricoltori. Med Lav 1986;77:184-90.

3. Dalphin JC, Bildstein F, Pernet D, Dubiez A, Depierre A. Prevalence of chronic bronchitis and respiratory function in a group of dairy farmers in the French Doubs province. Chest 1989;95:1244-7.

4. Vohlonen I, Tupi K, Terho EO, Husman K. Prevalence and incidence of chronic bronchitis and farmer's lung with respect to the geographical location of the farm and to the work of farmers. Eur J Respir Dis 1987;71 suppl 152:37-46.

5. Katila ML, Mäntyjärvi R A, Ojanen TH. Sensitisation against environmental antigens and respiratory symptoms in swine workers. Br J Ind Med 1981;38:334 8.

6. Donham KJ, Zavala DC, Merchant JA. Respiratory symptoms and lung function among workers in swine confinement buildings: a cross-sectional epidemiological study. Arch Environ Health 1984;39:96-101.

7. Donham KJ, Haglind P, Peterson Y, Rylander R. Environmental and health studies in swine confinement buildings. Am J Ind Med 1986;10:289-93.

8. Haglind $\mathbf{P}$, Rylander R. Occupational exposure and lung function measurements among workers in swine confinement buildings. J Occup Med 1987;29:9047.

9. Bongers P, Houthuijs D, Remijn B, Brouwer R, Biersteker K. Lung function and respiratory symptoms in pig farmers. Br J Ind Med 1987;44:819-23.

10. Holness DL, O'Blenis EL, Sass-Kortsak A, Pilger C, Nethercott JR. Respiratory effects and dust exposures in hog confinement farming. Am J Ind Med 1987; $11: 571-80$.

11. Iversen M, Dahl R, Korsgaard J, Hallas T, Jensen EJ. Respiratory symptoms in Danish farmers: an epidemiological study of risk factors. Thorax 1988;43:872-7.

12. Dosman JA, Graham BL, Hall D, Pahwa P, McDuffie $\mathrm{HH}$, Lucewicz M, et al. Respiratory symptoms and alterations in pulmonary function tests in swine producers in Saskatchewan: results of a survey of farmers. J Occup Med 1988;30:715-20.

13. Barthel E, Krecklow K. Epidemiologische Querschnittsstudie zur Prävalenz von chronischer Bronchi- tis und Lungenfunktionsstörungen bei Schweinezüchtern und Melkern. Z Erkr Atmungsorgane 1989; 172:143-9.

14. Wilhelmsson J, Bryngelsson IL, Ohlson CG. Respiratory symptoms among swedish swine producers. Am J Ind Med 1989;15:311 -8.

15. Donham K, Haglind P, Peterson $\mathrm{Y}$, Rylander R, Belin L. Environmental and health studies of farm workers in Swedish swine confinement buildings. $\mathrm{Br} \mathrm{J}$ Ind Med 1989;46:31-7.

16. Iversen M, Dahl R, Jensen EJ, Korsgaard J, Hallas T. Lung function and bronchial reactivity in farmers. Tho$\operatorname{rax} 1989 ; 44: 645$-9.

17. Iversen M, Pedersen B. Relation between respiratory symptoms, type of farming, and lung function disorders in farmers. Thorax 1990;45:919-23.

18. Donham KJ. Health effects from work in swine confinement buildings. Am J Ind Med 1990;17:17-25.

19. Cormier Y, Boulet L-P, Bedard G, Tremblay G. Respiratory health of workers exposed to swine confinement buildings only or to both swine confinement buildings and dairy barns. Scand $\mathbf{J}$ Work Environ Health 1991;17:269-75.

20. Crook B, Robertson JF, Travers Glass SA, Botheroyd EM, Lacey J, Topping MD. Airborne dust, ammonia, microorganisms, and antigens in pig confinement houses and the respiratory health of exposed farm workers. Am Ind Hyg Assoc J 1991;52:271-9.

21. Heederik D, Brouwer R, Biersteker K, Boleij JSM. Relationship of airborne endotoxin and bacteria levels in pig farms with the lung function and respiratory symptoms of farmers. Int Arch Occup Environ Health 1991;62:595-601.

22. Zhou C, Hurst TS, Cockcroft DW, Dosman JA. Increased airways responsiveness in swine farmers. Chest 1991;99:941-4.

23. Zuskin E, Zagar Z, Schachter EN, Mustajbegovic J, Kern J. Respiratory symptoms and ventilatory capacity in swine confinement workers. Br J Ind Med 1992; 49:435- 40 .

24. Rylander R, Donham KJ, Hjort C, Brouwer R, Heederik D. Effects of exposure to dust in swine confinement buildings - a working group report. Scand J Work Environ Health 1989;15:309-12.

25. Donham KJ, Popendorf WJ. Ambient levels of selected gases inside swine confinement buildings. Am Ind Hyg Assoc J 1985;46:658-61.

26. Donham KJ, Scallon LJ, Popendorf W, Treuhaft MW, Roberts RC. Characterization of dusts collected from swine confinement buildings. Am Ind Hyg Assoc J 1986;47:404-10

27. Attwood P, Brouwer R, Ruigewaard P, Versloot P, De Wit R, Heederik D, Boleij JSM. A study of the relationship between airborne contaminants and environmental factors in Dutch swine confinement buildings. Am Ind Hyg Assoc J 1987;48:745-51.

28. Rask-Andersen A, Malmberg P, Lundholm M. Endotoxin levels in farming: absence of symptoms despite high exposure levels. Br J Ind Med 1989;46:412-6.

29. Virtanen T, Kalliokoski P, Vilhunen P, Taivainen A, Mäntyjärvi R. Concentrations of specific dusts in swineries and the humoral response of swinery workers. Allergy 1990;45:354-62.

30. Malmberg P, Larsson K. Acute exposure to swine dust causes bronchial hyperresponsiveness in healthy subjects. Eur Respir J 1993;6:400-4.

31. Matson SC, Swanson MC, Reed CE, Yunginger JW. IgE and IgG-immune mechanisms do not mediate occupation-related respiratory or systemic symptoms in hog farmers. J Allergy Clin Immunol 1983;72:299304 .

32. Rylander R, Essle N, Donham KJ. Bronchial hyperreactivity among pig and dairy farmers. Am J Ind Med $1990 ; 17: 66-9$. 
33. Larsson K, Eklund A, Malmbreg P, Belin L. Alterations in bronchoalveolar lavage fluid but not in lung function and bronchial responsiveness in swine confinement workers. Chest 1992;101:767-74.

34. O'Connor G, Sparrow D, Taylor D, Segal M, Weiss $\mathrm{S}$. Analysis of dose-response curves to methacholine: an approach suitable for population studies. Am Rev Respir Dis 1987;136:1412-7.

35. Hervé-Bazin B. Guide d'évaluation de l'exposition au risque toxique sur les lieux de travail par échantillon- nage de l'atmosphère. Cah Notes Doc Secur Hyg Trav 1989;135:265-88.

36. Donham KJ, Zavala DC, Merchant JA. Acute effects of the work environment on pulmonary functions of swine confinement workers. Am J Ind Med 1984;5: $367-75$.

Received for publication: 23 February 1993 